\title{
Dietary Habits, Perceptions and Barriers Among Government and Private College Intermediate Students in Karachi: A Cross-Sectional Survey
}

Mariam Rashid, Sabeela Noor, Khadija Abdus Salam, Ramsha Irfan, Ayesha Siddique

$-----------------------------------------$ ABSTRACT

Objective: To determine differences in eating practices, perceptions, and perceived barriers among intermediate students of government and private sectors in Karachi.

Study design and setting: A cross-sectional study was conducted in six intermediate colleges of Karachi from October to December 2018.

Methodology: Total N=390 students aged 16-24 years were selected via non-probability convenience sampling. The study team developed a questionnaire to assess the dietary habits and barriers among the students.

Results: Mean BMI of government college students was $20.41 \pm 4.15 \mathrm{~kg} / \mathrm{m}^{2}$ while that of private college students was $22.25 \pm 5.43 \mathrm{~kg} / \mathrm{m}^{2}$. The proportion of underweight participants was higher (36.8\%) in government college students, and overweight students being higher in private $(23.8 \%)$. Similar responses were recorded for daily meals and weekly fastfood and fruit consumption. Skipping meals was found out to be a common practice among students. Breakfast was most commonly skipped meal among both groups $(23.9 \%$ \& $39.2 \%$, respectively). Watching television during meals was common in both groups (58.7\% \& $67.7 \%$ respectively). The majority of the students from both groups did not familiar with the term body mass index BMI (84.6\% \& 82.5\%, respectively). Smoking was more common among the private sector, $16.9 \%$, compared to $3.5 \%$ of the government sector. Fruit juice was considered a healthier option ( $58.7 \%$ \& $52.9 \%$, respectively). Similarly, white bread against bran bread was perceived healthier by the majority in both groups $(70.1 \%$ \& $59.3 \%$, respectively). Carbohydrate was reported as a major nutrient in the diet by $(51.7 \%$ \& $57.1 \%$ respectively). Factors like educational stress, time, will-power to maintain the diet, availability of junk food, and climate were some of the significant influencers of diet/lifestyle recorded.

Conclusion: Students from both groups shared similar eating and lifestyle practices irrespective of their educational institutes' status.

Keywords: Barriers, College Students, Dietary Habit, Perceptions.

How to cite this Article:

Rashid M, Noor S, Salam KA, Irfan R, Siddique A. Dietary Habits, Perceptions and Barriers Among Government and Private College Intermediate Students in Karachi: A Cross-Sectional Survey. J Bahria Uni Med Dental Coll. 2021; 11(2):81-86 DOI: https://doi.org/ 10.51985/ECXV5827

This is an Open Access article distributed under the terms of the Creative Commons Attriution Non Commercial Liciense (http:// creativecommons/org/licences/by-nc/4.0) which permits unrestricted non commercial use, distribution and reproduction in any medium, provided the original work is properly cited.

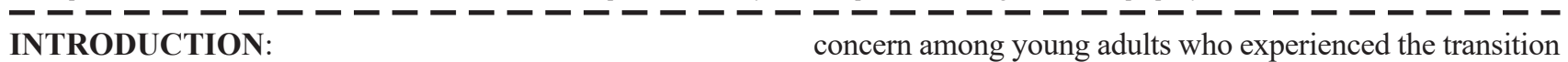

Unhealthy eating habits are a significant public health

\begin{tabular}{|c|}
\hline $\begin{array}{l}\text { Mariam Rashid } \\
\text { Final Year Student, MBBS } \\
\text { Jinnah Medical \& Dental College, Karachi, Pakistan }\end{array}$ \\
\hline $\begin{array}{l}\text { Sabeela Noor } \\
\text { Senior Lecturer, Department of Biochemistry } \\
\text { Jinnah Medical \& Dental College, Karachi, Pakistan } \\
\text { Email: sabeelanoor.noor@gmail.com }\end{array}$ \\
\hline $\begin{array}{l}\text { Khadija Abdus Salam } \\
\text { Final Year Student, MBBS } \\
\text { Jinnah Medical \& Dental College, Karachi, Pakistan }\end{array}$ \\
\hline $\begin{array}{l}\text { Ramsha Irfan } \\
\text { Final Year Student, MBBS } \\
\text { Jinnah Medical \& Dental College, Karachi, Pakistan }\end{array}$ \\
\hline $\begin{array}{l}\text { Ayesha Siddique } \\
\text { Final Year Student, MBBS } \\
\text { Jinnah Medical \& Dental College, Karachi, Pakistan }\end{array}$ \\
\hline $\begin{array}{l}\text { Received: 04-02-2021 } \\
\text { Accepted: 22-03-2021 }\end{array}$ \\
\hline
\end{tabular}
into academic life. They are exposed to stress, loads of work, peer pressure, and lack of time. ${ }^{1,2}$ Rapid physical growth and psychosocial development have placed these young adults as nutritionally vulnerable groups with poor eating habits that fail to meet dietary requirements. Some common unhealthy eating patterns among young adults included skipping meals, eating away from home, snacks, and fastfood consumption., ${ }^{3,4}$

Existing data shows the rising incidence and prevalence of malnutrition among youth. ${ }^{4,5}$ This is due to unhealthy eating and living practices, as most of the college students were not meeting dietary and physical activity guidelines. ${ }^{4}$ The average college student gets junk food twice a day as more frequently and easily than any other person. Consequently, young people are a higher rate of morbidity, disability, and mortality from various developmental, behavioral, and environmental risk factors than the general population. ${ }^{6}$

Nutrition is one of the major lifestyle factors related to 
developing many non-communicable diseases (NCDs). ${ }^{7}$ Eating a healthy diet and adopting a healthy lifestyle is instrumental in reducing risk factors for several major diseases like; anemia, metabolic syndrome, stroke, myocardial infarction, etc. Some of these have a very high mortality rate. Healthy eating is particularly significant for children and young people for proper growth and cognitive development, preventing major health problems from developing and ensuring a long and healthy life.,

In a survey conducted among the college students in California, over half of the subjects rated their diet as poor, with lack of time listed as the topmost barrier to eating well, and breakfast was the most commonly missed meal. ${ }^{10}$ Similarly, in one of the local studies conducted in Karachi, there was no difference between medical and non-medical students' perceptions regarding 'work-related stress' in their life. 'Lack of time' was cited as the most reason for skipping meals and being a barrier to exercising regularly among both groups. Based upon their research, the knowledge, attitudes, and practices of medical students in Karachi suggest that superior knowledge about a healthy lifestyle does not necessarily result in better practices. ${ }^{11}$

There are many interwoven factors influencing adolescents eating behaviors, from personal and cognitive factors to parental and media influences. ${ }^{12}$ Some important barriers to healthy eating as reported by previous researches are lack of knowledge, lack of self-control, the influence of media, time limitations, cost-effectiveness, lack of cooking skills, social and family pressure, personal preferences, wrong perception about weight, nature of food available at home and school/college, and habits ingrained from childhood. ${ }^{13-}$

15 Facilitators of a healthful diet included support from family, wider availability of healthy foods, and willpower. ${ }^{16}$

There is a significant difference between the socio-economic status, cultural milieu, and the resources available to the students of the government and private colleges in Karachi. ${ }^{17}$ Assessing dietary habits, perception, and the barriers they faced enabled us to determine whether there was any major difference between the two groups.

The results of this study may be utilized to develop better interventional strategies to promote healthy eating by overcoming the identified barriers, and in the long run, to prevent the emerging cases of NCDs related to nutrition.

\section{METHODOLOGY:}

A KAP survey was conducted among the students of intermediate colleges of Karachi. A non-probability convenience sampling was used for the primary data. The sample size of 390 was calculated by taking a $95 \%$ confidence interval with the range of anticipated proportion of $49 \%$ to $55 \%$ with a precision of $5 \%$, using an online OpenEpi calculator. ${ }^{11}$

The participants were students from Government and private intermediate colleges in Karachi, both male and female, aged between 16 and 24. Approval to conduct the study was granted by Jinnah Medical and Dental College's ethics committee, Karachi number: ERB-1019/JMDC dated on October 09,2018 . The study was conducted in six intermediate colleges in Karachi, Pakistan. Three colleges from the government and three from the private sector were visited for data collection after permission, on the colleges' administrations' allotted time and date. The names of colleges are not mentioned for the sake of confidentiality. All the consenting students were included and asked to complete the questionnaire in their classrooms during recess, whereas non-consenting students were excluded from the study. The study was conducted from October to December 2018.

The questionnaires were distributed and recollected by the members of the research team. Prior to questionnaire distribution, students were explained why they were suitable candidates for the chosen research and the goals of the study. The questionnaire was designed by reviewing the literature. ${ }^{10-}$ ${ }^{12}$ It consisted of the following four parts: Part (A) included the participants' demographic data. Part (B) was used to assess dietary and lifestyle habits. Part (C) demonstrated the participants' perception of healthy eating. This part also included a picture guide of a healthy eating plate as a reference to some questions. In Part (D), the participants were asked to identify the barriers encountered in maintaining healthy dietary habits.

Weight $(\mathrm{kg})$ and Height $(\mathrm{m})$ of participants were recorded using manual weight and height scale, respectively, and BMI was calculated using the Weight $(\mathrm{kg}) /$ height $\left(\mathrm{m}^{2}\right)$ formula. The data were analyzed using SPSS (Version 22). Simple statistical techniques were used to tabulate the results of the study. For nominal data mean, median, and standard deviation were recorded while for the categorical data, frequencies and percentages were computed. A Chi-square $\&$ fischer exact test was applied to describe the characteristics of the study sample. $\mathrm{P}$ value of $=0.05$ was considered as statistically significant.

\section{RESULTS:}

\section{Demographics:}

A total of 390 (Government $n=201$ \& Private $n=189$ ) intermediate college students participated in the study. Male participants $(52.7 \%$ govt. / $65.1 \%$ private) were greater in number than female participants $(47.3 \%$ govt. / 34.9\% private). The response rate was $100 \%$. The mean age for government and private college students (male, female) was $17.05 \pm 3.90$ and $17.34 \pm 1.32$ years respectively. The mean BMI of government college students was $20.41 \pm 4.15 \mathrm{~kg} / \mathrm{m}^{2}$ while that of private college students was $22.25 \pm 5.43$ $\mathrm{kg} / \mathrm{m}^{2}$. Based on their BMI, participants from both groups were categorized as underweight (below 18.5), normal (18.524.9), and overweight (above 24.9). About half of the participants, $50.8 \%$ (49.3\% govt. / 52.4\% private) had BMI 
Mariam Rashid, Sabeela Noor, Khadija Abdus Salam, Ramsha Irfan, Ayesha Siddique

in normal ranges. The proportion of underweight participants was higher $(36.8 \%)$ in the government college students than private college students $(23.8 \%)$. The overweight student population was higher $(23.8 \%)$ in private colleges as compared to that in government colleges $(13.9 \%)$.

\section{Dietary habits:}

The dietary habits and lifestyle of participants were assessed through various questions and presented in table 1 . The participants were inquired about the number of meals per day, weekly fast-food and fruit consumption, and daily water intake. Habits like skipping meals, physical exercise, watching T.V during meals, counting calories, and smoking were also assessed. Participants were asked about the effect of stress on their diet and familiarity with the concept of BMI. About half of the students $(51.2 \%)$ belonging to government colleges reported skipping meals, while the proportion of private college students who skip meals was slightly higher (58.7 $\%$ ). Breakfast was the most commonly skipped meal among the groups $(23.9 \% / 39.2 \%$ respectively) followed by lunch

Table-1: Comparison of dietary habits of the study population

\begin{tabular}{|c|c|c|c|}
\hline Parameters & $\begin{array}{c}\text { Government } \% \\
\mathrm{n}=\mathbf{2 0 1}\end{array}$ & $\begin{array}{c}\text { Private } \% \\
\text { n }=189\end{array}$ & P Value \\
\hline $\begin{array}{l}\text { Meals/day } \\
3 \text { or less } \\
\text { More than } 3\end{array}$ & $\begin{array}{l}49.3 \\
50.7\end{array}$ & $\begin{array}{l}61.9 \\
38.1\end{array}$ & $0.043 *$ \\
\hline $\begin{array}{l}\text { Fast food } \\
3 \text { or less } \\
\text { More than } 3\end{array}$ & $\begin{array}{l}75.6 \\
24.4\end{array}$ & $\begin{array}{l}74.1 \\
25.9\end{array}$ & $0.040 *$ \\
\hline $\begin{array}{l}\text { Fruit consumption } \\
3 \text { or less } \\
\text { More than } 3\end{array}$ & $\begin{array}{l}32.3 \\
67.7\end{array}$ & $\begin{array}{l}44.4 \\
55.6\end{array}$ & $0.222 *$ \\
\hline $\begin{array}{l}\text { Water intake } \\
<8 \text { glasses } \\
>8 \text { glasses }\end{array}$ & $\begin{array}{l}62.2 \\
37.8\end{array}$ & $\begin{array}{l}67.2 \\
32.8\end{array}$ & $0.577 *$ \\
\hline Skip Meals & 51.2 & 58.7 & $0.083 * *$ \\
\hline $\begin{array}{l}\text { Skipped Meal } \\
\text { None } \\
\text { Breakfast } \\
\text { Lunch } \\
\text { Dinner }\end{array}$ & $\begin{array}{c}48.8 \\
23.9 \\
18.4 \\
9.0\end{array}$ & $\begin{array}{c}41.3 \\
39.2 \\
13.2 \\
6.3\end{array}$ & $0.012 *$ \\
\hline $\begin{array}{l}\text { Exercise } \\
\text { Daily } \\
\text { Sometimes } \\
\text { Never }\end{array}$ & $\begin{array}{l}15.4 \\
67.7 \\
16.9\end{array}$ & $\begin{array}{l}19.0 \\
58.2 \\
22.8\end{array}$ & $0.149 *$ \\
\hline Watch T.V & 58.7 & 67.7 & $0.041 * *$ \\
\hline Count calories & 6.5 & 6.9 & $0.515^{* *}$ \\
\hline Smoke & 3.5 & 16.9 & $0.000 * *$ \\
\hline $\begin{array}{l}\text { Stress effects diet? } \\
\text { Eats more } \\
\text { Eats less } \\
\text { Not affected }\end{array}$ & $\begin{array}{l}20.4 \\
37.3 \\
42.3\end{array}$ & $\begin{array}{l}23.3 \\
36.5 \\
36.9\end{array}$ & 0.783 \\
\hline Familiar with BMI & 15.5 & 17.5 & 0.342 \\
\hline $\begin{array}{l}{ }^{*} \text { Chi-square } \\
* * \text { fishcer exact test }\end{array}$ & & & \\
\hline
\end{tabular}

(18.4\% / 13.2\% respectively). During meals, watching television was a common practice, $58.7 \%$ for government and $67.7 \%$ for private students. The majority of both groups were not familiar with the concept of BMI at all $(84.6 \%$ / $82.5 \%$ ). Smoking was reported more by private college students, $16.9 \%$, compared to $3.5 \%$ of government college students.

\section{Perception}

This section comprised several questions that helped to assess the perception of participants regarding a healthy diet. In one of the questions, the participants were asked to select the healthier option from the given choices, i.e., healthy vs. unhealthy. The choices were as follows: raw fruit vs. fruit juice, butter vs. margarine, bran bread vs. white bread, cooked food vs. processed food, and milk vs. carbonated drinks. It was found that fruit juice was perceived healthier than raw fruit $(58.7 \% / 52.9 \%)$. Similarly, white bread against brown bread was cited as a healthier option by many among both the groups (70.1 \% / $59.3 \%)$. On inquiring about the major nutrients, carbohydrate was reported as a major nutrient of diet by many $(61.2 \%$ and $61.4 \%)$.

Table-2: Comparison of perception of Healthy Diet

\begin{tabular}{|c|c|c|c|}
\hline Parameters & $\begin{array}{c}\text { Govt. } \\
(\%)\end{array}$ & $\begin{array}{c}\text { Private } \\
(\%)\end{array}$ & P Value \\
\hline $\begin{array}{l}\text { Raw Fruit Vs. Fruit Juices } \\
\text { Raw fruit } \\
\text { Fruit juices }\end{array}$ & $\begin{array}{l}41.3 \\
58.7\end{array}$ & $\begin{array}{l}47.1 \\
52.9\end{array}$ & $0.147 * *$ \\
\hline $\begin{array}{l}\text { Butter Vs. Margarine } \\
\text { Butter } \\
\text { Margarine }\end{array}$ & $\begin{array}{l}78.6 \\
21.4\end{array}$ & $\begin{array}{l}70.4 \\
29.6\end{array}$ & $0.04 * *$ \\
\hline $\begin{array}{l}\text { Bran bread Vs. White bread } \\
\text { Brown bread } \\
\text { White bread }\end{array}$ & $\begin{array}{l}29.9 \\
70.1\end{array}$ & $\begin{array}{l}40.7 \\
59.3\end{array}$ & $0.016 * *$ \\
\hline $\begin{array}{l}\text { Cooked food Vs. Processed } \\
\text { food } \\
\text { Cooked food } \\
\text { Processed food }\end{array}$ & $\begin{array}{l}88.1 \\
11.9\end{array}$ & $\begin{array}{l}91.0 \\
9.0\end{array}$ & $0.217 * *$ \\
\hline $\begin{array}{l}\text { Milk Vs. Carbonated drinks } \\
\text { Milk } \\
\text { Carbonated drinks }\end{array}$ & $\begin{array}{l}81.1 \\
18.9\end{array}$ & $\begin{array}{l}70.9 \\
29.1\end{array}$ & $0.012 * *$ \\
\hline $\begin{array}{l}\text { Major portions } \\
\text { Carbohydrates } \\
\text { Fat } \\
\text { Proteins } \\
\text { Fiber }\end{array}$ & $\begin{array}{l}61.2 \\
22.4 \\
51.7 \\
44.8\end{array}$ & $\begin{array}{l}61.4 \\
24.9 \\
47.1 \\
38.1\end{array}$ & 0.192 \\
\hline $\begin{array}{l}\text { Food at canteen } \\
\text { Healthy } \\
\text { Junk }\end{array}$ & $\begin{array}{l}10.4 \\
89.6\end{array}$ & $\begin{array}{c}7.4 \\
92.6\end{array}$ & \\
\hline $\begin{array}{l}\text { Views } \\
\text { Needs improvement } \\
\text { Fine } \\
\text { Not bothered }\end{array}$ & $\begin{array}{c}44.8 \\
49.3 \\
6.0\end{array}$ & $\begin{array}{l}56.6 \\
38.1 \\
5.3\end{array}$ & \\
\hline $\begin{array}{l}\text { Eating Plate } \\
\text { Almost same } \\
\text { More or less same } \\
\text { Completely different }\end{array}$ & $\begin{array}{l}29.9 \\
48.8 \\
21.4\end{array}$ & $\begin{array}{l}30.2 \\
51.9 \\
18.0\end{array}$ & 0.684 \\
\hline
\end{tabular}


Protein was the second-most reported major nutrient (51.7 $\%$ and $57.1 \%$ ) followed by fiber and then fat. Food available at college canteens was considered junk food by majority of government and private college students $(89.6 \% \& 92.6 \%$ respectively). On the illustration of a healthy eating plate through the questionnaire, nearly half of the participants from the government $(48.8 \%)$ and private $(51.9 \%)$ reported that their eating plate is "more or less same" to the one provided in the guide. When questioned regarding their dietary habits, around half (49.3\%) of government college students considered their eating habits acceptable. In contrast, more than half (56.6\%) of the students from private colleges thought that they need improvement in their eating habits.

\section{Barriers}

In this section, the participants identified the barriers faced by them in maintaining a healthy diet. Numerous barriers were classified into the following three categories: personal barriers, social barriers, and environmental barriers. Among the personal barriers, lack of will power to maintain a healthy diet $(39.3 \%)$ and lack of time $(53.4 \%)$ was the highest reported barrier by government and private college students. Out of various social factors, "Educational stress" ranked highest $(51.7 \%$ and $56.1 \%$ ), which was also the overall highest reported barrier (53.8\%). "Easy access to unhealthy food" was recorded as the most commonly faced environmental barrier (44.8\% / 51.3\%). Refer to the table no. 3

\section{DISCUSSION:}

The purpose of this study was to assess dietary practices, perceptions, and barriers to healthy eating among college students in Karachi and to study any differences in these factors concerning the educational institution status of either

Table-3: Perceived barriers to healthy eating by the students

\begin{tabular}{|l|c|c|c|}
\hline Barriers & Govt. \% & Private \% & Total\% \\
\hline Personal Barriers & 30.8 & 35.4 & 33.1 \\
Lack of motivation & 30.8 & 22.8 & 26.9 \\
Lack of knowledge & 30.3 & 32.8 & 31.5 \\
Lack of cooking skills & & & \\
Lacking will power to maintain & 39.3 & 46.6 & 42.8 \\
healthy diet & 32.3 & 33.9 & 33.1 \\
Personal preference & 32.8 & 53.4 & 42.8 \\
Lack of time & & & \\
& & & \\
Social Barriers & 19.4 & 21.7 & 20.5 \\
High cost of food & 20.4 & 23.8 & 22.1 \\
Depression & 51.7 & 56.1 & 53.8 \\
Educational stress & 19.4 & 30.7 & 24.9 \\
Media influence & 36.8 & 37.6 & 37.2 \\
Influence of family/friend & & & \\
& & & \\
Environmental Barriers & 09.0 & 11.6 & 10.3 \\
Ethnic preference & 42.3 & 35.4 & 39.0 \\
Climate & 44.8 & 51.3 & 47.9 \\
Easy access to unhealthy food & 19.9 & 13.8 & 16.9 \\
No access to healthy food & 19.9 \\
\hline
\end{tabular}

government or private sector. Our study showed that although the mean BMI was within normal ranges in both groups, about half of the population had abnormal BMI values, more students falling in the underweight category (30.5\%). This contrasts with research conducted on college students in Saudi Arabia ${ }^{18}$ and Oman ${ }^{19}$ that showed a higher percentage of overweight/obese students, $37.5 \%$ and $28.22 \%$, respectively, compared to only $18.7 \%$ overweight/ obese students in our study in Karachi. Underweight students' prevalence was more in government college students, while overweight/obese students were more among private sector students. Past research in Karachi indicated 27\% underweight and $22 \%$ overweight college students ${ }^{20}$. Another previous study on government sector medical college students in Karachi demonstrated the higher prevalence of underweight students. ${ }^{21}$

The comparison of eating habits showed only slight differences between the two groups. In terms of meal frequency, the overall majority reported consuming only three or fewer meals per day, including snacks, the percentage being higher in private sector students than government sector students. The majority of students in both groups consumed fast-food only three or fewer times a week. The majority in both groups reported a weekly fruit consumption of more than three times but, a higher percentage was seen in government sector students. Almost similar frequencies of daily water intake of fewer than eight glasses were found among both groups. Meal skipping was a common practice with breakfast being the most commonly skipped meal of the day among the general student population. These results were consistent with various previous researches identified in a systematic review, demonstrating skipping meals, especially breakfast, a common practice among the youth and students ${ }^{10,22}$. Exercise patterns did not differ among the two groups, and the majority from both groups found to exercise only sometimes. Watching television was found out to be more common in private sector students. Only a negligible proportion of students in both groups practiced calorie counting. Smoking was more common in private college students as compared to government college students. Almost similar effects of stress on diet were noted in both groups. Generally, students were not familiar with the concept of BMI irrespective of their educational institute's status.

The perception regarding healthy or unhealthy food choices was nearly similar; however, there were slight differences in terms of reported percentages, for example, the larger number of a participants from government colleges considered white bread healthier than brown (bran) bread and similarly, a greater number of participants among private students perceived carbonated drinks as healthy. Likewise, similar responses were noted in both groups regarding major dietary nutrients both in terms of frequency and order of the nutrients. The food usually available at college canteens was considered as unhealthy/junk by the great majority of 
both groups. On comparing their usual eating plate with a standard one, the majority from both groups perceived their eating plates as more or less similar to the standard eating plate; moreover, the proportions of students that perceived their eating plate as almost the same or completely different from the standard were also comparable. Despite having about similar eating habits and perceptions, it was seen that more of the private college students believed that they need improvement in their eating habits whilst the majority of government students were fine with their current eating habits. The study explored various personal, social, and environmental factors prevailing in young students that hinder healthy lifestyles and dietary practices. Again, nearly similar percentages were observed between the two groups with slight variations. Among the government institute students, the top three encountered barriers were educational stress, climate influence, and easy access to unhealthy food. It included educational stress, lack of time, and easy access to unhealthy food for private institute students. Although educational stress was identified as the most commonly faced barrier among the general student population, lack of time and media influence were the additional major factors influencing private college students' habits. Influence of family and friends was also a significant barrier to healthy lifestyle habits among youth. Results were supported by some similar researches done in the past that identified educational stress and lack of time as major factors influencing students' lifestyles along with the other identified barriers. ${ }^{10,11}$ To address the limitation: larger sample swould have more valid results. As the questionnaire was selfconstructed, providing proper validity is an issue.No funding was provided, self-financing was hindered to progress the project. Time constraints, mainly due to college timings and getting permission from institute heads should be addressed too. It is recommended that there is a need to create awareness and knowledge regarding a balanced healthy diet and a good dietary habit in both government and private intermediate college students of Karachi.

\section{CONCLUSION:}

Students from both groups shared more or less similar eating and lifestyle practices irrespective of the educational institutes' status with slight differences in terms of reported percentages and $p$ values. However, it was seen that more of the private college students believed that they need improvement in their eating habits while the majority of government students were fine with their current eating habits and lifestyles. The barriers encountered by students were also similar.

- - - - - - - - - - - - - -

Authors Contribution:

Mariam Rashid: Collected Data, writing draft

I Sabeela Noor: Design, Supervise and finalized

| Khadija Abdus Salam: Collecting data, writing draft, | |

Ramsha Irfan: Collected data, Analyzed data

Ayesha Siddique: Colleced data, Editing

\section{REFERENCES:}

1. Nelson MC, Story M, Larson NI, Neumark-Sztainer D, Lytle LA. Emerging adulthood and college-aged youth: an overlooked age for weight-related behavior change. Obesity. 2008;16(10):2205-11

2. Ganasegeran K, Al-Dubai SA, Qureshi AM, Al-Abed AA, Rizal AM, Aljunid SM. Social and psychological factors affecting eating habits among university students in a Malaysian medical school: a cross-sectional study. Nutrition journal. 2012;11(1):1-7.

3. Papadaki A, Hondros G, Scott JA, Kapsokefalou M. Eating habits of university students living at, or away from home in Greece. Appetite. 2007;49(1):169-76.

4. Huang TT, Harris KJ, Lee RE, Nazir N, Born W, Kaur H. Assessing overweight, obesity, diet, and physical activity in college students. Journal of American College Health. 2003;52(2):83-6.

5. Shields M. Overweight and obesity among children and youth. Health Rep. 2006;17(3):27-42.

6. Haberman S, Luffey D. Weighing in college students' diet and exercise behaviors. Journal of American College Health. 1998;46(4):189-91.

7. Kimokoti RW, Millen BE. Nutrition for the Prevention of Chronic Diseases. Med Clin North Am. 2016;100(6):118598. doi: 10.1016/j.mcna.2016.06.003. PMID: 27745589.

8. Ross R, Janiszewski PM. Is weight loss the optimal target for obesity-related cardiovascular disease risk reduction?. Canadian Journal of Cardiology. 2008 Sep 1;24:25D-31D.

9. Azadbakht L, Mirmiran P, Esmaillzadeh A, Azizi T, Azizi F. Beneficial effects of a Dietary Approaches to Stop Hypertension eating plan on features of the metabolic syndrome. Diabetes Care. 2005;28(12):2823-31. doi: 10.2337/diacare.28.12.2823. PMID: 16306540 .

10. Silliman K, Rodas-Fortier K, Neyman M. Survey of dietary and exercise habits and perceived barriers to following a healthy lifestyle in a college population. Californian journal of health promotion. 2004;2(2):10-9.

11. Sajwani RA, Shoukat S, Raza R, Shiekh MM, Rashid Q, Siddique MS, Panju S, Raza H, Chaudhry S, Kadir MM. Knowledge and practice of healthy lifestyle and dietary habits in medical and non-medical students of Karachi, Pakistan. Journal of the Pakistan Medical Association. 2009;59(9):650655.

12. Stevenson C, Doherty G, Barnett J, Muldoon OT, Trew K. Adolescents' views of food and eating: Identifying barriers to healthy eating. Journal of adolescence. 2007;30(3):41734.

13. World Health Organization. Diet, nutrition, and the prevention of chronic diseases: report of a joint WHO/FAO expert consultation. World Health Organization; 2003 Apr 22.

14. Krebs-Smith SM, Heimendinger J, Patterson BH, Subar AF, Kessler R, Pivonka E. Psychosocial factors associated with fruit and vegetable consumption. American Journal of Health Promotion. 1995;10(2):98-104.

15. Lappalainen R, Saba A, Holm L, Mykkanen H, Gibney MJ, Moles A. Difficulties in trying to eat healthier: descriptive analysis of perceived barriers for healthy eating. European journal of clinical nutrition. 1997;51(2):S36. 
Dietary Habits, Perceptions and Barriers Among Government and Private College Intermediate Students in Karachi

16. Atlantis E, Barnes EH, Ball K. Weight status and perception barriers to healthy physical activity and diet behavior. International journal of obesity. 2008;32(2):343-52.

17. Shepherd J, Harden A, Rees R, Brunton G, Garcia J, Oliver S, Oakley A. Young people and healthy eating: a systematic review of research on barriers and facilitators. Health education research. 2006;21(2):239-57.

18. Al-Rethaiaa AS, Fahmy AE, Al-Shwaiyat NM. Obesity and eating habits among college students in Saudi Arabia: a cross sectional study. Nutrition journal. 2010;9(1):1-10.

19. Al-Kilani H, Waly M, Yousef R. Trends of obesity and overweight among college students in Oman: A cross sectional study. Sultan Qaboos University Medical Journal. 2012;12(1):1-8
20. Khan K, Jameel N, Khalil R, Gul S. Exploring nutritional status, physical activity and body mass index of Pakistani teens. Int Journal Res Med Sci. 2016;(4):3563-9.

21. Minhas HT, Anis D, Jawaid A, Naeem H, Naz M, Zuberi BF. Estimation of body mass index in students of a public sector medical college in Pakistan. Pak J Med Sci. 2010;26(4):918 22.

22. Pendergast FJ, Livingstone KM, Worsley A, McNaughton SA. Correlates of meal skipping in young adults: a systematic review. International Journal of Behavioral Nutrition and Physical Activity. 2016;13(1):1-5.

\section{$\bullet \bullet \bullet \hat{\gamma} \cdot \bullet \cdot \bullet$}

